\title{
"The Effect of Waqf Literacy in Realizing Excellent Service for Waqf Administration by the Officer of Waqf Pledge Deed (PPAIW)" in 2020
}

\author{
Asnawati $^{1}$, M.E. Burhanudin ${ }^{2}$ \\ \{asnawatimardamin54@gmail.com¹, burhanudinbwi@gmail.com²\} \\ Research and Development Agency, Minister of Religion, Republic of Indonesia ${ }^{1}$, Indonesian Waqf
} Board $^{2}$

\begin{abstract}
Implementation of the Waqf in Indonesia relies on the officer of waqf pledge deed (PPAIW) as the official authorized to carry out the administrative process for doing waqf members in Indonesia, PPAIW has a role in providing legal certainty to safeguard waqf property, as a basis for information and data, as well as providing services and guidance functions in national waqf. In practice, PPAIW, which is authorized to carry out the administration process for waqf in Indonesia, is still not optimal in carrying out its duties, this is due to a lack of both administrative literacy and understanding of waqf law and regulations. This study uses qualitative research, which is research aimed at describing and analyzing phenomena, incidents or events, social activities, attitudes, perceptions, and human thoughts individually or in groups. Interviews were conducted directly with PPAIW, wakif, Nazhir, and the community in the area of the Religious Affairs Office (KUA) in Beji District, Depok City, the Office of Religious Affairs in Sukmajaya District, Depok City, the Office of Religious Affairs in East Bogor District, Bogor City and the Office of Religious Affairs in North Bogor District- Bogor city. The results showed that the waqf literacy for the officer of the Waqf Pledge Deed (PPAIW) was included in the low category, especially the administrative literacy of waqf, legal literacy and regulation of waqf and literacy about excellent service, only the Fiqh literacy of waqf was included in the high category. Waqf administrative services at the Office of Religious Affairs (KUA) are following the Standard Operational Procedures (SOP) written in the KUA, but there are some KUAs who do not have a written Standard Operating Procedure, so that the implementation of their services is following PPAIW habits and capabilities, and excellent service standards for Waqf services at KUA are not yet understood by PPAIW. The level of community satisfaction, wakif, and Nazhir with waqf services, the majority answered that they were satisfied with waqf services, but some people answered that they were not satisfied with waqf services, due to the still slow process of waqf and the inactivity of PPAIW in helping solve waqf administrative problems. The effect of low waqf literacy for PPAIW resulted in PPAIW's lack of understanding of the legality of waqf so that cases were found such as PPAIW issuing a letter of cancellation of a deed to replace the waqf deed pledge (APAIW) which resulted in the loss of the status of the waqf land, and it was found that PPAIW replaced Nazhir and issued the Waqf deed Pledge of every five once a year, giving rise to multiple AIWs in one donated land location.
\end{abstract}

Keywords: The Officer of the Waqf Pledge Deed, Waqf Literacy, excellent Service, the Waqf Pledge Deed. 


\section{Introduction}

Indonesia is a country with the largest Muslim population in the world. Therefore, the large Muslim population is one of the potentials that can be exploited to implement the role of waqf to create social justice to alleviate the poverty that is currently hitting Indonesia. Waqf has advantages over zakat, infaq, and alms. The zakat that is paid is then used and its form is exhausted as well as the benefits as well as alms and infaq. In contrast to waqf which has the main principle, namely in terms of waqf payment, the principal of the waqf must remain eternal while only the benefits are given so that the benefits of waqf remain as long as the principal is still there.

In principle, waqf has benefits, where the investment for waqf itself earns rewards from Allah almighty and can build the economy of the people. Waqf investment is an infrastructure to improve the quality of a decent life in the socio-economic aspect. (Attamimy, et al., 2013) Waqf as a social dimension of worship has very broad benefits for the public interest. In the provision of waqf, there is no limit to the amount and to whom the waqf is addressed as long as it does not violate sharia principles. Besides that, the development and management of waqf objects can continue to expand into the area of economic investment activity, because basically, waqf must indeed develop or increase in value so that the benefits provided are also greater.

Quoting Abdul Salam's opinion (http://abdulsaalam.blogspot.com/2012/09/revitalisasilembaga-wakaf-di-indonesia.html, which was accessed on February 5, 2020) The existence of waqf in the social constellation of society is expected to exist, because in Islam, waqf is not only a shock breaker to cope with momentary needs, but rather as a sub-system of Baitul Mal institutions. Waqf if managed professionally will be a potential source of funds for the development of the nation and state.

Waqf is one of the instruments in Islam to achieve the goal of Islamic economics, namely to create a prosperous life. Muslim countries such as Saudi Arabia, Jordan, Turkey, Bangladesh, Egypt, and Malaysia have implemented waqf as an instrument to increase various activities of the ummah and alleviate the problem of poverty. (Havita, et al., 2014.) In Islam, the practice of waqf has a very important position like zakat and alms. Waqf requires a Muslim to give up the assets given to be used in the interests of worship and goodness. Waqf assets that have been given are no longer a personal property but belong to the people. (Darwanto. 2012)

The practice of waqf in Indonesia, before the issuance of Law Number 41 of 2004 concerning Waqf, mostly occurred based on oral tradition (belief) without written evidence. People who want waqf, entrust more to religious leaders, such as Ulama, Kyai, Ajengan, Tengku, and so on. They are considered more trustworthy because they have religious authority. The practice of waqf at that time was more due to the factor of religious beliefs without considering the aspect of the ability of the recipient of the waqf mandate (Nazhir) to maintain the integrity and manage sustainably for the benefit of waqf property. (Sutami, et al., 2013)

Based on the results of the waqf literacy index survey conducted by the Indonesian Waqf Board and the Directorate of Zakat and Waqf that the value of the Waqf Literacy Index (ILW) as a whole scored 50.48 in the low category, consisting of the Basic Waqf Understanding Literacy Score of 57.67 and the Advanced Waqf Comprehension Literacy Score of 37.97. (Results of BWI Survey and Directorate of Zakat and Waqf, 2020)

If we look closely, many cases of waqf in Indonesia, such as misappropriation, disputes, disappearances and even the release of waqf property stems from an orderly problem of legal 
administration. How many waqf assets (especially waqf of land) have been lost or released due to the absence of AIW and or waqf certificates, such as cases of revocation or cancellation of the deed instead of the Waqf Pledge Deed (APAIW) in one of the Religious Affairs Office in Depok City which resulted in the loss of waqf property and even Nazhir was made a suspect because he was considered to have taken over the company's land which was actually waqf land, Nazhir's dispute caused by Nazhir's replacement which was issued by one of the Religious Affairs Office in Bekasi and other cases of waqfs.

In the general provisions of Law number 41 of 2004 concerning Waqf, the Officer of the Waqf Pledge Deed or abbreviated as PPAIW is the authorized officer appointed by the Minister of Religion of the Republic of Indonesia to make Waqf Pledge Deed (AIW). What is meant by an official here is a person who is given legal duties and authority to make AIW. Meanwhile, AIW is evidence of a statement of wakif's will to donate his property to be managed by Nazhir following the allotment of waqf property as stated in the "Deed.".

According to UNESCO (Puskas BAZNAS, 2019) literacy is divided into three aspects, namely: (1) ability to write, read and speak, (2) ability to count, (3) ability to access information and knowledge. In line with the definition of literacy described by UNESCO, the Big Indonesian Dictionary (KBBI) also explains that literacy is divided into three aspects, namely: (1) the ability to write and read, (2) skills or knowledge in a certain activity (3) a person's ability in processing information and knowledge. (KBBI Online, https://kbbi.kemdikbud.go.id/entri/literasi accessed on April 14, 2020) So, to find out a person's literacy level can be seen in these three aspects. (Puskas BAZNAS, 2019) Currently, there is no absolute meaning related to waqf literacy in textual books or research studies, so the direct meaning of waqf literacy has not been found. However, if the definition of waqf literacy is adjusted to the understanding of literacy in general, then waqf literacy means the individual's ability to read, understand, calculate and access information related to waqf which ultimately aims to increase one's awareness of waqf.

Excellent service etymologically means the best service or very good service. From the management aspect, excellent service is a key factor in the success of an organization (government or private). Within the government bureaucracy, good service to the community will increase the great or effective image building for the ministry or institution. Meanwhile, in the private sector, customer service will encourage positive growth and company profits. (Atep, 2001)

Operationally, excellent service does not stop at the meaning of "serving" according to existing standards but creates a wider space for community satisfaction. For example, in the bureaucratic environment of the Office of Religious Affairs (KUA) there are procedures for managing marriages for the community, to carry out these procedures there are Minimum Service Standards (SPM) which must be met by officers in the field. The basic concept of prime service must be understood in depth by PPAIW as part of an effort to build professionalism to support the management system and administration of waqf in general. Excellent service must be more than SPM, where field officers provide better service related to satisfaction. Examples of service elements have more to do with friendly attitudes or even other special treatment. By providing more services, it makes the community or KUA service users feel a higher level of satisfaction from the services provided, the real impact of this service will bring a more positive image or feeling to the community (service users).

Waqf service is an activity, process, and interaction and is a change in a condition in every human being, even in an extreme way it can be said that service cannot be separated from human life. (Sinabembela, 2010). According to Kotler, service to the community is any activity that benefits both individuals or groups and offers satisfaction even though the results 
are not tied to the product physically, in other words, service is direct or indirect interaction and provides satisfaction to society. (Philip Kotler and Kevin Lane Keller, 2006).

As one of the units that have the task and function of conducting research and development, the Center for Research and Development of Bimas for Religion and Religious Services feels responsible for following up on Article 1 Point 6 of Law Number 41 of 2004 concerning Waqf, namely "the Officer of Waqf Pledge Deed, hereinafter abbreviated as PPAIW, is the authorized officer appointed by the Minister to make a Waqf Pledge Deed". This is the main background for the birth of the idea to research "The Effect of Waqf Literacy in Realizing Excellent Service for Waqf Administration by the Officer of Waqf Pledge Deed (PPAIW)". At least, this research is specifically related to Waqf literacy for PPAIW and waqf administration services.

In essence, the implementation of waqf in Indonesia rests on PPAIW as the official authorized to carry out the administration process for waqf in Indonesia, PPAIW has the role of providing legal certainty to secure waqf property, as a basis for information and data, and providing services and guidance functions in national waqf. The duties of PPAIW are to examine the completeness of the administration of waqf, carry out the implementation of the Waqf Pledge, validate the AIW / APAIW, make a report on the handover of waqf, submit a copy of the AIW / APAIW to related parties, administer the waqf certificate, register, and process Nazhir's turn to BWI. Meanwhile, the PPAIW's authority is to check the validity of the administration of waqf, reject the implementation of the waqf pledge if administrative requirements and legal provisions have not been fulfilled, provide input or attention to candidate Wakif, candidate Nazhir, and prospective witnesses, propose replacing Nazhir and take part in the mediation process if it occurs a conflict among waqf stakeholders.

In practice, the Head of the Office of Religious Affairs as PPAIW who is authorized to carry out the administration process for waqf in Indonesia is still not optimal in carrying out its duties, this is due to a lack of literacy of waqf both administration and understanding of the law or waqf regulations for PPAIW, so that in the field implementation there are PPAIW which revoke or cancel AIW or APAIW that has been issued so that the property of waqf has no legal force, replacing Nazhir by reissuing the Wakaf Pledge Deed so that there are multiple AIWs in one location of waqf land, and the lack of PPAIW's active role in managing the issuance of waqf certificates at the National Land Agency ( BPN).

Some of the problems above still occur, causing conflicts or disputes over waqf to cause Nazhir to be unproductive in managing waqf because he focuses on dealing with conflicts or disputes in court. One of the indicators of excellent service in the process of waqf is the realization of an orderly administration of waqf to minimize the occurrence of conflicts or waqf disputes. (Iwan Fuad, interview, March 23, 2020)

Institutionally at the Ministry of Religion, the issue of waqf in Indonesia is the task and function of the Directorate General of Islamic Community Guidance. One of the 1st echelons in the Ministry of Religion is responsible for improving the quality of religious guidance, especially the duties and functions of the Officer of Waqf Pledge Deed (PPAIW). Together with the Directorate of Zakat and Waqf Empowerment and the Indonesian Waqf Board (BWI), in terms of maintaining and improving the quality of the Officer of Waqf Pledge Deed (PPAIW)). What is the objectivity of the problem and what policies should be taken to solve it are reasons for conducting field research? The Center for Research and Development of Bimas for Religion and Religious Services as a supporting system for the Directorate General of Islamic Community Guidance can take on this research role. 


\section{Problem Limitations}

Many things have caused disputes in Indonesia, ranging from the low literacy of waqf in the general public, the administrative problems of waqf to the arrival of third parties suing for waqf status. However, the authors give limits on the scope of the research to be conducted. Researchers only limited the problem to the influence of waqf literacy for the Waqf Pledge Deed Making Office (PPAIW) in creating excellent service in KUA Beji Sub-district and KUA Sukmajaya District Depok and KUA Districts of North Bogor and East Bogor Bogor. In this study, researchers wanted to find out how the low literacy of PPAIW waqf affects the excellent service of waqf administration.

\section{Background of Problems}

With the research background above, the focus of this research is more on waqf literacy for the Officer of the Waqf Pledge Deed (PPAIW). There are cases of waqf disputes caused by PPAIW to revoke and cancel AIW or APAIW resulting in weak legal certainty for waqf administration which causes waqf disputes, PPAIW issues AIW every five years in the process of changing nazhir, which results in multiple AIW in one location of the waqf land, due to a lack of literacy of waqf both in waqf law and administration of waqf for PPAIW. So, the problem can be formulated: How is the influence of waqf literacy in realizing excellent service by the Officer of the Waqf Pledge Deed (PPAIW)?

\section{Previous Studies}

Previous studies on the influence of waqf literacy in realizing service by PPAIW have not been done much. However, there are several studies with themes that are close to, among others: 1) Research on The Issue of Waqf Service in the Office of Religious Affairs (KUA) Keling district of Jepara Regency (2014), conducted by the lecturer of the Faculty of Economics and Business of Islam IAIN Walisongo Semarang. This descriptive qualitative analysis study found that the results of this study that the implementation of waqf in the Office of Religious Affairs of Keling Sub-District still lacks human resources in the field, waqf services are given to the community is not maximal. In general, the performance of officials in the Office of Religious Affairs does not affect the level of the economic well-being of the community, this is because the culture and management of waqf in Keling Sub-district are still traditional, individual, and not yet professional. 2) The Role of Productive Waqf for Public Welfare (Study Case of Nazhir Foundation In the University of Islam Malang) research by Yuli Rofai, Umar Burhan, Multifiah Multifiah. About Productive Waqf for VIP room (Very Important Person) in RSI Malang (Islamic Hospital of Malang) which is managed by the foundation of Nadzir in the University of Islam Malang is a pilot project of productive waqf that comes from the grants provided by the Ministry of Religious Affairs. The public strongly supports Productive Waqf for VIP room in RSI Malang and make the VIP room is never empty. So that in less than 7 (seven) years the VIP building has reached BEP (Break-Even Point). Nazhir foundation of the University of Islam Malang is also developing productive 
waqf by adding a VIP room and building an al Khaibar convenience store. The existence of a pilot project of a productive waqf VIP room and convenience store is perceived by the public. The construction of the VIP room in RSI Malang and the minimarket create new jobs for the people. Productive waqf which is managed Nazhir foundation in the University of Islam Malang is expected to be able to continue developing and give more benefit to society. (multifiah, et al., 2016) 3) The role of PPAIW and Nazhir in Waqf Land Certification in Depok District of Sleman Regency (2016), conducted by Fikri Hanif (UIN Student Sunan Kalijaga Yogjakarta. Research with this normative approach method concluded that in general PPAIW and Nazhir have done the task contained in the legislation, but there was negligence in the implementation of this task, both in PPAIW and Nazhir, which made the implementation of this legislation not maximal so that the waqf certification process has not been completed in its entirety. Also, Nazhir has performed the task beyond what has been determined by Law No. 41 of 2004 concerning Waqf which is related to the technical resolution of the problem that should be the duty of PPAIW.

The fundamental difference between the author's research with the title "The Influence of Waqf Literacy in Realizing The Excellent Service of Waqf Administration by the Waqf Pledge Deed Making Officer (PPAIW)", with previous research focusing on the influence of waqf literacy, Nazhir and Wakif satisfaction on PPAIW Services, PPAIW's performance in implementing waqf administration, and improved competence and waqf literacy for PPAIW, so that this research can complement previous research.

\section{Discussion}

\subsection{Literacy}

Based on the large Indonesian dictionary, namely knowledge or skills in certain fields or activities, while waqf literacy can mean knowledge or skills in the field of waqf be it administration of waqf, fiqh of waqf and law or waqf regulation. Reporting from (Wikipedia, https://id.wikipedia.org/wiki/Literasi accessed on April 13, 2020) the term literacy in Latin is referred to as literatus, which means a person who learns. Broadly speaking, literacy itself is a general term that refers to a person's ability and skills in reading, writing, speaking, calculating, as well as solving problems in everyday life. In other words, literacy cannot be separated from one's ability to speak the language. Whereas in the EDC or Education Development Center, literacy is defined as an individual's ability to use his / her potential which means that the ability is not limited to reading and writing.

The views of several experts related to literacy, including according to Alberta: the ability to write, read, and enrich knowledge by promoting effective problem-solving. This ability is expected to be communicated efficiently to contribute to the life of the wider community. According to the World Economic Forum, there are 6 levels/types of literacy, including numeracy, which is the ability to answer problems that arise in everyday life, automatically being able to analyze as a basis for decision making. (Salamadian, https://salamadian.com/pengertian literacy accessed on 12 April 2020).

According to the National Institute for Literacy, it defines Literacy as an individual's ability to read, write, speak, calculate, and solve problems at the skill level required in work, family, and society. (https://www.dosenpendidikan.co.id/literasi-adalah/ accessed on 12 April 2020)

This study uses qualitative research, which is research aimed at describing and analyzing phenomena, incidents or events, social activities, attitudes, perceptions, and human thoughts individually or in groups. (M. Djunaidi Ghony and Fauzan Almanshur, 2017) Primary data 
sources and data collection techniques in this study use observation, interview, and documentation techniques. (Sugiyono, 2011).

Geographical condition of the Office of Religious Affairs in Beji District, Depok City, is located in the Depok Mulya 1 Housing Complex, with a land area of $250 \mathrm{~m} 2$ and a building area of $180 \mathrm{~m} 2$, the Office of Religious Affairs (KUA) of Sukmajaya District is located at Jalan Merdeka No.2, Mekar Jaya, Sukmajaya District, Depok City, was established in 1986 with a total of 50 million rupiahs from the State Budget and the Islamic Religious Education office in 1990, with a land area of $298.90 \mathrm{~m} 2$. The Office of Religious Affairs (KUA), East Bogor District is located on Riau Street No.5, RT.01 / RW.03, Baranangsiang, East Bogor District, Bogor City, East with an area of 1,015 ha, the Office of Religious Affairs, North Bogor District which is located at Jalan Artzimar II No.1, RT.03 / RW.02, Tegal Gundil, North Bogor District, Bogor City with an area of 494 Ha Agriculture and Non-Agriculture covering 1,502 Ha.

\subsection{Waqf}

The word waqf itself comes from the verb "wakafa (fiil madi) — yaqifu (fiil mudori) - waqfan (isim masdar) which means stop/stand. (Ahmad Azhar Basyir, 1987) According to the term, waqf is the legal act of a person or legal entity that separates part of the assets in the form of land owned and institutionalizes it forever for worship and other public purposes following Islamic teachings. (Sofyan Hasan, 1992). According to Imam Syafii, waqf is a form of religious activity. Waqf is valid if the wakif has stated in words of wakaftu (I have given waqf), even without the judge's decision. Al Jairi added that the meaning of holding back in the term waqf means that the waqf goods cannot be granted. (Abdul Ghofur Anshori, 2006).

In Islamic history, waqf has been known since the time of the Prophet (peace be upon him) because waqf was prescribed after the prophet in Medina, in the second year of Hijriyah. Two opinions have developed among experts in Islamic jurisprudence (fuqaha') regarding who was the first to implement the waqf law. According to some opinions, the scholars said that the first to implement waqf was Rasulullah Muhammad (peace be upon him), namely using waqf land belonging to the Prophet (peace be upon him) to build a mosque. Rasulullah (peace be upon him) in the third year of Hijriyah donated the seven-date palms in Medina; among them are A'raf, Shafiyah, Dalal, Barqah, and other cultivation. Then the waqf sharia that was carried out by Umar bin Khattab followed by Abu Talhah who donated his favorite cultivation, "Bairaha". (Indonesian Waqf Board, https://www.bwi.go.id/sejarahperkembangan-wakaf/ accessed on 14 April 2020)

The majority of scholars divide the pillars of waqf into 4 , among others:

a. Waqif (the person who donated his property).

b. Mawquf (the assets that are donated). 
c. Mawquf 'alaih (The purpose of waqf / the person entrusted with managing the waqf property called nazir).

d. Sighah (waqif's speech to donate his property). (Haq Faishal, 2014)

The function of waqf in social life is as follows:

a. Waqf can foster the nature of helping and the nature of zuhud in charity, and waqf can also provide benefit to fellow Muslims.

b. Waqf can be the most potential source in increasing the interests of the people, such as welfare, economy, education, health, da'wah, and so on.

c. Waqf is expected to be a solution to various economic problems, and to be able to independent Muslims from dependence on various parties who are not in line with Muslims.

d. Waqf can raise awareness that in every legal personal property, these assets must still have a social function. (Imam Kamaludin, et al., 2018)

In the pre-independence era of Indonesia, waqf was a tradition of the majority of Muslim Indonesian people. This phenomenon arose because many Islamic empires ruled in this archipelago. Among them are the Demak kingdom, the Samudera Pasai kingdom, and the Mataram kingdom. This then makes waqf an integral part of Indonesian culture. The establishment of mosques, Islamic boarding schools, and educational institutions based on waqf has been popular and can be found in various parts of the country. (Djunaidi, et al., 2007)

Waqf has been regulated by unwritten customary law and is only based on religious values. Even so, in the Dutch colonial era, several waqf regulations were issued. Likewise, after Indonesia's independence, the government issued regulations relating to waqf, until the present era Law Number 41 of 2004 concerning waqf was issued. This is a government effort to protect waqf property, provide legal certainty for wakif and Nazhir candidates, as well as an effort to advance waqf in Indonesia. (Attamimy, et al., 2013).

\subsection{Excellent Service}

Excellent service etymologically means the best service or excellent service. From a management aspect, excellent service is a key factor in the success of an organization (government or private). Within the government bureaucracy, good service to the community will increase the great or effective image building for the ministry or institution. Meanwhile, 
in the private sector, customer service will encourage positive growth and company profits. (Atep Adya, 2001)

The principles of best service to customers or society (service users) lie in three important things that must be considered, (Sutami, et al., 2013) that is:

a. Attitude

Attitude is a response to a person's actions, both active and passive. Regarding service in the field that is expected to be built in an employee is a good attitude, friendly, sympathetic, empathetic, and has a high sense of belonging to the organization or company.

The main attitudes in excellent service can be explained as follows:

(1) Having pride in their work, pride in their duties and functions will be manifested in satisfying services for service users.

(2) Having great devotion to work, serving with sincerity will foster excellent service.

(3) Maintaining the dignity and good name of the organization or company, the responsibility of employees is to always maintain the good name of the organization or company so that it is always good in the eyes of the community (service users).

b. Attention

The sensitivity of employees in paying attention to and observing the needs of the community (service users) is one of the principles that must be carried out because it can increase the interest and comfort of the community as service users.

The forms of service based on the concept of attention are as follows:

(1) Saying the opening greetings, the principle of this opening greeting is the enthusiasm of officers/employees to people who need service with a welcome, open, and ready to serve attitude.

(2) Asking the public about the needs politely and sympathetically.

(3) Listening to and understanding the wishes of the community carefully so as not to ask repeated questions.

(4) Serving quickly, precisely and friendly, service response is the most important factor demanded by the community (service users).

(5) Prioritizing the community, placing the interests of the community at number one (Customer Oriented) there is no element of personal or group interest so that services run optimally and there is no deviation from authority.

c. Action 
The concept of action is a direct response to the wishes or needs of the community in the form of services provided by officers, aspects of actions taken by officers involve administrative and guidance elements that become their duties and functions.

The forms of service based on the concept of action can be described as follows:

(1) Immediately record the needs of the community as service users.

(2) Reaffirming the needs of society.

(3) Resolving community needs.

(4) Showing polite treatment in the hope that the community can get satisfaction.

4. The Officer of the Waqf Pledge Deed

In Article 1 point 6 of Law Number 41 of 2004 concerning Waqf, it is explained that the Officer of the Waqf Pledge Deed or abbreviated as PPAIW is an authorized official appointed by the Minister of Religion of the Republic of Indonesia to make a Waqf Pledge Deed (AIW). PPAIW as the official authorized to carry out the administrative process of waqf in Indonesia, PPAIW has the role of providing legal certainty to secure waqf property, as a basis for information and data, as well as providing services and guidance functions in national waqf. PPAIW's duties are to examine the completeness of the administration of waqf, carry out the implementation of the Waqf Pledge, validate the AIW / APAIW, make a report on the handover of the waqf, submit a copy of the AIW / APAIW to related parties, administer the waqf certificate, register, and process Nazhir's turnover to BWI. Meanwhile, PPAIW's authority is to check the validity of the administration of waqf, reject the implementation of the waqf pledge if administrative requirements and legal provisions have not been fulfilled, provide input or attention to candidate Wakif, candidate Nazhir, and potential witnesses, propose replacing Nazhir and take part in the mediation process if this occurs a conflict among waqf stakeholders. (Sutami, et al., 2013)

The Officer of the Waqf Pledge Deed (PPAIW) is the authorized officer appointed by the Minister of Religion to make the Waqf Pledge Deed, such as the Head of the Religious Affairs Office designated as PPAIW who is authorized to issue AIW / APAIW for land waqf, while for PPAIW cash waqf are Institutional Officials Sharia Finance is at the lowest level at the level of the Head of the LKS Section appointed by the Minister of Religion. (Government Regulation Number 42 of 2006 concerning Implementation of Law Number 41 of 2004 concerning Waqf). 


\section{Research Results and Analysis}

\subsection{Waqf Literacy for the Officer of the Waqf Pledge Deed}

Of the four research locations, namely the Office of Religious Affairs (KUA), Beji District, the Office of Religious Affairs (KUA), Sukmajaya District, the Office of Religious Affairs (KUA), East Bogor District and the Office of Religious Affairs (KUA), North Bogor District, Waqf literacy for officers of waqf Pledge deed (PPAI) is still included in the low category, especially the administrative literacy of waqf, legal literacy and regulation of waqf and literacy about excellent service, this is different from the fiqh literacy of waqf which is still high, because the majority of PPAIW's educational background is from the Akhwal Syakhsiyah department ( Islamic Family Law) at the Sharia Faculty.

As explained by Mr. Dede Nafis as the Head of KUA Beji Depok Subdistrict that: (Interview with Mr. Dede Nafis PPAIW KUA Beji)

"Honestly, we still don't read the regulations on waqf, moreover, there are many regulations that change from time to time, so that the implementation is following what we previously understood, even coaching the KUA has only been carried out twice by the Ministry of Religion ”(Interview with Mr. Dede Nafis PPAIW KUA Beji)

Literacy in general is the individual's ability to process and understand information while reading or writing. Literacy is more than just the ability to read and write, therefore, literacy cannot be separated from language skills, namely written and spoken language knowledge which requires a series of cognitive abilities, knowledge of genres, and culture. (https://www.literasipublik.com/pengertian-literasi accessed on 23 July 2020)

The term literacy in Indonesian is a loan word from English literacy which etymologically comes from the Latin literatus, which means people who learn. In Latin, there is also the term littera (letter), which is a writing system with accompanying conventions. (https://www.literasipublik.com/pengertian-literasi accessed on 23rd July 2020)

The increase in waqf literacy for PPAIW is still low, this is due to the lack of waqf references in the KUA and also education and training for PPAIW has not been intensely implemented, the role of the Ministry of Religion and the Indonesian Waqf Board is very important in increasing literacy both administration and law of waqf which will improve PPAIW's competence as the frontline in securing waqf property. The many obstacles experienced by PPAIW in the field are homework for PPAIW to discipline the administration of waqf, so that waqf has a strong legal standing so that it can minimize problems or disputes on waqf in the future. 
From this description, the basic concept of waqf literacy for PPAIW can be explained as follows:

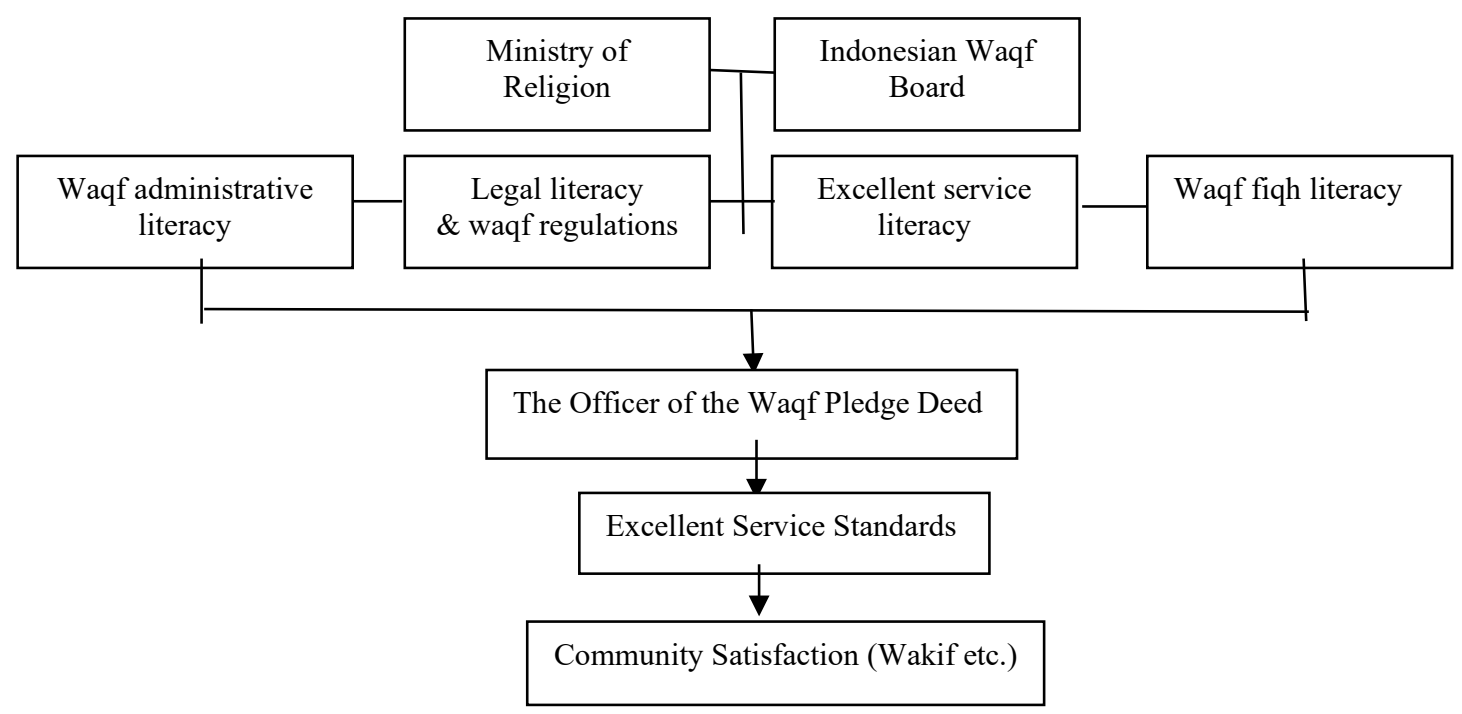

Image: the basic concept of waqf literacy

Literacy for PPAIW such as waqf administrative literacy, waqf law and regulations, service standards, and waqf fiqh should be regularly improved by the Ministry of Religion together with BWI in the form of references to books, journals, and other media such as ebooks, articles and so on. Also, education and training should be routinely carried out to improve literacy and competence for PPAIW so that PPAIW waqf services can exceed excellent service standards for the community.

In the process of appointing the head of the KUA as well as serving as PPAIW without any competency tests or special requirements to become PPAIW, in carrying out his duties and functions, the head of the KUA in addition to focusing on dealing with marriage coupled with his duties as the officer of the waqf pledge deed. Waqf education and training for PPAIW are not routinely carried out every year, so PPAIW has not received special attention to improving literacy and competence in terms of waqf. (interview with PPAIW KUA Beji, KUA Sukmajaya, KUA East Bogor and KUA of north Bogor).

\subsection{Waqf Administration Services at the Office of Religious Affairs}

The officials of Waqf pledge deed (PPAIW) must be able to provide the best service to waqf stakeholders. PPAIW is one of the most important elements in national waqf related to the administration system and legally securing waqf property. (Sutami, et al., 2013)

Waqf administrative services at the Office of Religious Affairs (KUA) already have standard procedures in terms of stages for waqf, time limits that must be met when the requirements for waqf have not been met, but not all KUA have written service standards so that in practice implemented following the capabilities and habits of PPAIW. (Interview with PPAIW in Beji District).

From the aspect of administrative requirements for the implementation of waqf, PPAIW must be careful to see whether all the requirements stipulated in the legislation have 
been fulfilled or not. The requirements that need to be seen before the occurrence of waqf are as follows: (Sutami, et al., 2013)

a. PPAIW must ensure that the wakif candidate has met the legal requirements so that the person concerned can take legal actions legally.

b. PPAIW must ensure the status of waqf assets.

c. PPAIW must pay attention to the best Nazhir candidate based on an objective money assessment and meet Nazhir's requirements following statutory provisions.

d. PPAIW must pay close attention to the allocation of waqf assets.

Standard Operating Procedures (SOP) for waqf services in several KUAs already exist, but there are still KUAs that do not yet have an SOP for waqf services, so in practice, PPAIW carries out waqf services under the capabilities and daily habits of service at the KUA. In the waqf land certification process, KUA only provides a cover letter, and a statement that the waqf is not in dispute, the waqf land certification process is carried out by Nazhir. In practice in the field, PPAIW plays a very large role in administering waqf assets. However, between PPAIW and the National Land Agency (BPN) and the Indonesian Waqf Board (BWI), more intense coordination is still needed. This is due to frequent problems in the process of donating land certification and also in the process of changing the Nazhir of the donated land. (Interview with PPAIW)

Although the arrangement for the certification of waqf land has been regulated in the Joint Decree of the Head of the National Land Agency and the Minister of Religion of the Republic of Indonesia Number 422 of 2004 concerning the Certification of Waqf Land, problems are still found in the field, including : (Sutami, et al., 2013)

a. The SKB or Tax-Free Decree explains that the cost of the waqf land certification is borne by the budget of the Ministry of Religion to then be distributed to Nazhirs in the management of waqf land certification after being coordinated with the Ministry of Religion at the Regency / City level. However, compared to the number of waqf lands that do not have a certificate, certification assistance is far from adequate.

b. The standard difference in the arrangement of each parcel between regions. For example, the ministry of religion stipulates 1 million rupiahs for assistance for one parcel, but in some areas, the cost is still relatively small, so that in the field it often encounters obstacles. If the assistance is adjusted to the standard cost of BPN in all locations, the difficulty level in data collection is very high because many regions have donated land.

c. Bureaucratic factors that take a long time in processing the donated land certification at BPN, although the schedule has been clearly defined, non-technical obstacles are often found, such as the attitudes of individuals relating to costs outside the existing provisions.

d. PPAIW still find that they do not care about the management of the donated land certificate, which is their main task, the reluctance of PPAIW is caused by several things such as the lack of budget or even the absence of fees for obtaining the waqf land certificate, or often encountering bureaucratic obstacles.

\subsection{Level of Satisfaction with Waqf Services at KUA}

The level of community satisfaction is determined by the quality of service at the KUA, the success of PPAIW in providing waqf services to the community based on principles that lie in three important things that must be considered, namely : (Sutami, et al., 2013) a. Attitude

PPAIW must have a good attitude, friendly, sympathetic, empathetic, and have a high sense of belonging to the organization or institution. 


\begin{abstract}
b. Attention
In carrying out service activities, PPAIW must always pay attention to the condition of the community, and also PPAIW must be able to become a motivator, facilitator, and public service.

\section{c. Action}

The concept of action is a direct response to the wishes or needs of the community in the form of waqf services provided by PPAIW, both in terms of administrative elements or guidance, which are their duties and functions.

The results showed that the majority of respondents answered that they were satisfied with the waqf service at KUA, with a total of 11 out of 12 respondents who were satisfied, this shows that the service of waqf is good in the community. However, 1 in 12 respondents answered that they were not satisfied with the service of waqf, namely community representatives due to the slow process of waqf at the KUA and the inactivity of PPAIW in helping to solve the administrative problems of waqf, this means that PPAIW is still slow in responding to the wishes or needs of the community in waqf service.
\end{abstract}

\title{
4. The Effect of Waqf Literacy
}

The officers of the Waqf Pledge Deed (PPAIW) are one of the important pillars in advancing national representation. Based on Law Number 41 of 2004 concerning Waqf, PPAIW is the authorized officer appointed by the Minister of Religion to make the Waqf Pledge Deed (AIW). Among the main tasks of PPAIW are providing waqf administration and serving the needs of prospective wakifs who will donate part of their assets properly. (Sutami, et al., 2013) The low literacy of waqf, especially administration, regulation, and the law of waqf, resulted in PPAIW's lack of understanding of the legality of waqf which harmed Nazhir, wakif, and society. There are case findings such as the letter of cancellation of the Waqf Pledge Deed (APAIW) replacement deed issued by PPAIW which resulted in the loss of the status of the waqf land, which was found in one of the KUA in the Depok City area, and PPAIW which issued AIW every five years in the process of changing Nazhir, which results in the existence of multiple AIWs in one waqf land location found in one of the KUA in Bogor city.

The role and function of the KUA as the spearhead of waqf security is very important, therefore it is necessary to increase the competence of the officer of the waqf pledge deed both in terms of administration, service, and also waqf law. Cases of waqf in Indonesia, such as misappropriation, disputes, disappearances, and even the release of waqf property stems from an orderly problem of legal administration. (Indonesian Waqf Board https://www.bwi.go.id/5016/2020/06/24/meningkatkan-peran-dan-fungsi-kua-sebagai-ujungtombak-pengamanan-wakaf/ accessed on 23 August 2020).

\section{Conclusion}

Based on the data analysis that has been done, it is concluded that: Waqf literacy for officers of the Waqf Pledge deed (PPAIW) is in a low category, especially the administrative literacy of waqf, legal literacy and regulation of waqf, and literacy about excellent service, only the fiqh literacy of waqf which is included in the high category because the majority of PPAIW are alumni of the sharia faculty. Waqf administrative services at the Office of Religious Affairs (KUA) are following Standard Operating Procedures (SOP) in written waqf administrative services at KUA, but there are some KUAs who do not have written SOPs and PPAIW does not yet understand the excellent service standards for waqf services. The level of community satisfaction, wakif, and Nazhir with waqf services, the majority answered that they 
were satisfied with the waqf service at the KUA, but there were still people who answered that they were not satisfied with the waqf service, due to the slow process of the waqf in the KUA and the inactivity of PPAIW in helping solve the administrative problems of waqf. The influence of low waqf literacy for PPAIW, especially administration, regulation, and waqf law, resulted in a lack of understanding of the legality of waqf, resulting in cases such as PPAIW issuing a letter of cancellation of a deed replacement of waqf pledge deed (APAIW) which resulted in the loss of the status of the waqf land, and PPAIW found that issuing a Waqf Pledge Deed every five years in the process of changing Nazhir, which results in multiple AIWs in one waqf land location.

\title{
8 Research Suggestion
}

From the above conclusions, the researchers can suggest that as material recommendations from the results of this study, are as follows:

1. For the Officers of the Waqf Pledge Deed (PPAIW) at the Office of Religious Affairs, to continue to improve waqf literacy, especially waqf administration, waqf law and regulations and excellent service, which aims to improve service quality, especially in the area of waqf, so that the community, waqf, and Nazhir feel Satisfied and assisted in the process of waqf administration so that it can anticipate if in the future the status of the waqf land is challenged by outsiders because the waqf land has a strong legal standing.

2. For the Ministry of Religion to participate in carrying out the function of monitoring, coaching, education, and training regularly as well as providing facilities that support the performance of the Officers of the Waqf Pledge Deed (PPAIW) at the Office of Religious Affairs, due to the low literacy of waqf, especially the administration of waqf, law and waqf regulations and excellent service, so that in practice there are still many waqf services that are not optimal.

3. For the Indonesian Waqf Board (BWI) in addition to performing optimal and comprehensive control, guidance, and supervision functions of Nazhir, it must also collaborate with the Ministry of Religion to provide education and training for PPAIW regularly so that the management of waqf can run following statutory regulations

Acknowledgments. Research and Development Agency, Minister of Religion, Republic of Indonesia

\begin{abstract}
About The Author/s
Asnawati Mardamin was born in Jakarta on 3 October 1954. She completed her undergraduate education at the Dahwah faculty of IAIN Sunan Ampel Surabaya and graduated in 1987, in 1989 she became a civil servant at the Ministry of Religion, and in 2017 as a principal expert researcher besides that she was a researcher at Puslitbang at Bimas Religion and Religious Services Research and Development Agency and education and training at the Ministry of Religion.

M.E. Burhanudin, born in Pandenglang 23 August 1996, took bachelor and master education at UIN Sunan Gunung Djati Bandung, majoring in Sharia Economic Law, has worked as a teacher at SMK Tunas Bangsa, Manager of Service and Operations at BMT itQan Bandung and staff of the Institutional and Advocacy Division of the Indonesian Waqf Board, actively
\end{abstract}


writing on the bincanghukum.id website, write articles on the bwi.go.id website and participate in research at the central Balitbang at the Ministry of Religion.

\section{References}

Anshori, Abdul Ghofur. Law and Waqf Practice in Indonesia, Yogyakarta: Pilar Media, 2006.

Asnawati and Muhamad E. Burhanudin. 2020. "Waqf Literacy in Realizing Excellent Service for Waqf Administration by the Officer of the Waqf Pledge Deed (PPAIW)". the results of personal interviews: July 2020, KUA Beji Depok city, KUA Sukmajaya Kota Depok, KUA of East Bogor Bogor city and KUA of North Bogor-Bogor City.

Attamimy, Et al. The Dynamics of Waqf in Indonesia and Various Parts of the World. Jakarta: Director General of Bimas Islam, 2013.

Indonesian Waqf Board, https:/www.bwi.go.id/5016/2020/06/24/meningkatkan-peran-dan-fungsikua-sebagai-ujung-tombak-pengamanan-wakaf/ accessed on 23 August 2020

Indonesian Waqf Board, https://www.bwi.go.id/sejarah-perkembangan-wakaf/ accessed on 14 April 2020

Barata, Atep Adya. The Basics of Excellent Service, Preparation to Build a Culture of Excellent Service to Increase Customer Satisfaction and Loyalty, Jakarta: Elex Media Komputindo, 2001.

Basyir, Ahmad Azhar. Islamic Law regarding Waqf, Syirkah, Bandung: PT. Al Maarif, 1987.

Djunaidi M. Ghony \& Fauzan Almanshur, Qualitative Research Methodology, Jogjakarta: ArRuzz Media, 2017.

Djunaidi, Ahmad, Thibieb Al-Asyhar, Towards the Era of Productive Waqf. Jakarta: Mumtaz Publishing, 2007.

Haq Faishal. Waqf Law in Indonesia. Sidoarjo: CV. Dwiputra Pustaka Jaya, 2014.

Hasan, Sofyan. Introduction to the Law of Zakat and Waqf, Surabaya: Al-Ikhlas, 1992.

Kamaluddin Imam \& Tim. Practical Waqf Fiqh (Basic). Ponorogo: Gontor Press, 2018.

Literasi Numerasi, https://salamadian.com/pengertian literacy accessed on 12 April 2020

Muhamad E. Burhanudin. 2020. "Waqf Disputes Data in the Indonesian Waqf Board". the results of personal interviews: March 23, 2020, Indonesian Waqf Board-Jakarta

Multifiah, Yuli Rofai, Umar Burhan, The Role of Productive Waqf for Public Welfare (Study Case of Nadzir Foundation In University of Islam Malang), International Journal of Social and Local Economic Governance (IJLEG) Vol. 2, No. 2, October 2016.

Definition of literacy, https://www.dosenpendidikan.co.id/literasi-adalah/ accessed on 12 April 2020

Definition of literacy, https://www.literasipublik.com/pengertian-literasi accessed on 23 Juli 2020

Government Regulation Number 42 of 2006 concerning Implementation of Law Number 41 of 2004 concerning Waqf

Center for Strategic Studies of the National Amil Zakat Agency (Puskas BAZNAS), Zakat Literacy Index: Theory and Concepts, Jakarta: Puskas BAZNAS, 2019.

The results of the Waqf Literacy Index Survey, BWI, BAZNAS and the Directorate of Zakat and Waqf, Presented at the Public Expose Event results of the 2020 Zakat and Waqf Literacy Index Survey. Wednesday, 20 May 2020.

Sugiyono, Research Methodology of Quantitative Qualitative and R\&D, Bandung: Alfabeta, 2011.

Sutami, Et al. Waqf Service Standards for the Officers of the Waqf Pledge Deed (PPAIW), Jakarta:

Director General of Bimas Islam, 2013.

Wikipedia, https://id.wikipedia.org/wiki/Literasi accessed April 13, 2020

Puspa, Ida Ayu Tary. 2012. "Pemimpin Perempuan yang Balinese dalam Perspektif Hindu". Jurnal Studi Jender Srikandi, Volume 1, November 2012.

Putri, Risa Herdahita. 2017. Para Sultanah di Kesultanan Aceh. 16 Desember 2017. https://historia.id/kuno/articles/para-sultanah-di-kesultanan-aceh-P1BJ0, accessed 25 August 2020.

"Studi Kepustakaan", Pengertian, dan (Tujuan-Peranan-Sumber-Strategi). https://www.gurupendidikan.co.id/studi-kepustakaan-pengertian-tujuan-peranan-sumber-strategi/, accessed 1 April 2020. 
Sugiyono. 2008. Metode Penelitian Kuantitatif Kualitatif dan R \&D. Bandung: Alfabeta.

Suyami. 2008. Konsep Kepemimpinan Jawa dalam Ajaran Sastra Cetha dan Astha Brata. Yogyakarta: Kepel Press.

Tumpi Readhouse Budaya. 2016. Dasanama, Padanan Kata dalam Bahasa Jawa. 2 Mei 2016. https://tumpi.id/dasanama-padanan-kata/, accessed 5 Agustus 2020.

Wahab, Abdul Azis. 2008. Anatomi Organisasi dan Kepemimpinan Pendidikan. Bandung: Alfabeta. 